\title{
Education of Hypno-parenting Method on Successfulness of Toilet Learning of Toddlers
}

\author{
Wahyuningsih Safitri ${ }^{1)}$, Wahyu Rima Agustin ${ }^{2}$ \\ ${ }^{1)}$ Nurse Professional Study Program, Kusuma Husada University, Surakarta \\ ${ }^{2}$ Nursing Undergraduate Study Program at Kusuma Husada University Surakarta \\ *E-mail: wahyuningsihsafitri@gmail.com \\ https://doi.org/10.30787/gaster.v19i1.535
}

ARTICLE INFO

Keywords: Toilet Learning;

Hypno-Parenting; Toddler

\section{ABSTRACT}

Stages of child development tasks that must be achieved at toddler age are toilet learning. Toilet learning is an effort to train children to be able to control bowel movements and urination. Education about toilet learning can be done using the hypnoparenting method. The purpose of this study was to determine the effect of hypno-parenting health education methods on the success of toilet learning in toddler age children. This research is a quantitative study, with a quasi-experimental research design with pre-test and post-test nonequivalent control group. The sampling technique is done by using non probability sampling technique with the number of research respondents as many as 44 children. The toilet learning success measurement tool in this study used the toilet learning success questionnaire. Data analysis in this study used the Wilcoxon and Mann Whitney tests because the data were not normally distributed. The results showed that $p$ value 0,000<0.05 then $\mathrm{HO}$ was rejected and $\mathrm{Ha}$ was accepted so there was an influence of hypno-parenting health education method on the success of toilet learning in toddler age children.

\section{INTRODUCTION}

Toddler period is a period of intensive environmental exploration because the child tries to find out how it all happened. This period is an important period for achieving child development and growth (Wong, 2009). Children aged 1-3 years (toddler) are called as golden age, because children aged 0-5 are at their best growth. Children can quickly absorb information received from outside, 
thus whatever the child receives will have an impact on him. However, each child will complete tasks with different and varied techniques, some fail, slow, fast or very fast (Erwin, 2013).

One of the stages of child development tasks that must be achieved at toddler age is toilet learning (Supartini, 2012). According to Sigmund Freud (1856-1939) in the anal phase, the main focus of children is on controlling the bladder and defecation. The role and duties of the family is in an effort to support children's growth and development to be independent. Parents can support to paying attention to the environment and bathroom facilities that are easily accessible to children (Rahayu and Firdaus, 2017).

Toilet training for children is an effort to train children to be able to control their urination and defecation (Umami, 2011). Toilet learning can be successful depending on the child readiness and the ability of parents to know the right time for their child's development stages. Usually after 1 year old, childs are aware of their body and the things they do. It is not uncommon for babies aged 18 months who actually already know that peeing and defecating is natural, but they will say pee and e'e 'after they do it. Most of the children showed signs of being ready physically, mentally, and emotionally between the ages of 24 and 36 months (Effendi, 2011). The problem arising from the obstacle in toilet learning is that children cannot control defecation (BAB) and urination (BAK) (Murdiana et al, 2017).

Education is a learning interaction process that is planned to influence the attitudes and skills of other people, be it individuals, groups, or communities, so as to do what educators expect. Education is also an effort to add new knowledge, attitudes and skills through strengthening certain practices and experiences (Soekidjo, 2014). The instruments used to provide education about toilet learning and hypnoparenting were booklets and leaflets.

According to Siswoyo, et al (2011), the family is the first and foremost center of education, because it is in that family that the child's personality is formed. Thus, as long as the child is at home, parenting style is very important, especially in giving attention to their child. However, it is not not an attitude of spoiling their children, but rather giving sufficient attention to developing and training children's independence.

Data from the Indonesian Ministry of Health (2013) shows that the number of toddlers in Indonesia is quite large, around 
17,091,762 people out of 87.9 million Indonesian children. In Indonesia it is estimated that the number of children under five years old is estimated to reach $30 \%$ of the 250 million population of Indonesia. In addition, according to the National Household Health (SKRT) survey (2012) it is estimated that the number of children under five years old who have difficulty controlling defecation and urination (bedwetting) until preschool reaches 75 million children. This phenomenon is triggered by many reasons, such as, lack of knowledge about how to practice bowel and bowel movements, use of disposable diapers, the presence of new siblings and many other things.

According to the results of a preliminary study conducted by Kiftiyah et al in 2018 in PAUD I, Sooko Village, Sooko District, Mojokerjo Regency, $60 \%$ of 10 children still wet the bed, and $25 \%$ still use diapers. Ammelda et al's (2013) research found that in a child care center in Pekanbaru, interviewing 10 mothers who had children aged 2-3 years, stated that they chose to use diapers on the grounds that they were more practical and there was not enough time for their children to work, 1 mother who has a 29 month old child said that her child had problems when defecating so she required to use diapers.
Based on the data obtained by researchers on November 26, 2018, there were 50 toddlers in Randusari Village, Jebres sub-district, a preliminary study conducted by researchers by interviewing 10 mothers who have children aged 1-3 years; 7 out of 10 mothers said their children still wet the bed, 3 others said their children said e'e 'and peed when they wanted to defecate and urinate.

Toilet learning or bowel and bladder training is included in psychomotor development because it requires maturity of the muscles in the anal area and urinary tract. The exercise should be started when the child is 15 months old and it would be unwise to train children less than 15 months of age, as this can lead to traumatic experiences. Toilet learning is a moral exercise that is accepted for the first time by children and is very influential on the moral development of the next child (Suherman, 2010).

Hypnoparenting in children is a condition that exists in alpha and theta thought waves, which have phenomena such as feelings of daydreaming or imagination. In a hypnotic state, a child easily accepts positive suggestions that are useful for development, from childhood to adolescence. These positive suggestions will be stored in their subconscious mind (Willi and Andri, 2009). 
This hypnoparenting method is simple, easy, inexpensive, non-invasive, harmless, and effective/is best done by parents in parenting by giving suggestions to children compared to adults (Sutiyono, 2010). Hypnoparenting techniques are more towards indirect hypnosis techniques. The essence of hypnosis techniques for children is how to build appropriate and efficient communication relationships between parents and the environment towards children (Suhendri, 2011).

Yendrizal (2014) stated that, Hypnoparenting can also be used to increase appetite in children because preschool children tend to not be able to think logically, tend to respond to stimuli they receive without further consideration. 95\% of words, actions and attitudes from parents and environmental influences will easily enter the child's subconscious mind as if they were not filtered out or digested.

\section{METHOD AND RESOURCES}

This research is a quantitative research. The design of this study was a quasi experiment using pre-test and post-test nonequivalent control group. The research design that will be used is the pre test and post test nonequivalent control group, which means that the respondents are divided into two groups. One treatment group and one control group as a comparison. This research was conducted in January 2019. The population in this study were toddlers. The sampling technique in this study used a non probability sampling technique. The sample of this study was 44 toddlers. The data in this study were analyzed using the Wilcoxon and Mann Whitney tests.

\section{RESULTS AND DISCUSSION}

1. Univariate Analysis Analisa Univariat

Table 1 Distribution Frequency of Respondent Characteristics Based on Age

\begin{tabular}{|c|c|c|c|c|c|}
\hline \multirow{2}{*}{\multicolumn{2}{|c|}{ Age }} & \multicolumn{2}{|c|}{ Intervention } & \multicolumn{2}{|c|}{ Control } \\
\hline & & $f(n)$ & $\%$ & f (n) & $\%$ \\
\hline $\begin{array}{l}\text { Age } \\
\text { year }\end{array}$ & & 2 & $9,1 \%$ & 1 & $4,5 \%$ \\
\hline $\begin{array}{l}\text { Age } \\
\text { year }\end{array}$ & & 9 & $40,9 \%$ & 8 & $36,4 \%$ \\
\hline $\begin{array}{l}\text { Age } \\
\text { year }\end{array}$ & 3 & 11 & $50,0 \%$ & 13 & $59,1 \%$ \\
\hline Total & & 22 & $100 \%$ & 22 & $100 \%$ \\
\hline
\end{tabular}

The results of this study indicate that the age of respondents in the intervention group was at most 3 years old with 11 children (50.0\%) and the control group with 13 children (59.1\%). The results of this study are in line with research 
conducted by Atti (2014) which shows that the majority of respondents are 3 years old.

According to Armawati (2011) toilet training should not be done for children under 1 year old because it forces children who are not ready to do it. Children are able to be trained to control defecation after 18-24 months old and usually mastered more quickly than urination control, but in general children can actually control bowel movements when they are around 3 years old (Soetjaningsih, 2012).

Tabel 2 Distribution Frequency of Respondent Characteristics Based on Gender

\begin{tabular}{lcccc}
\hline \multirow{2}{*}{ Gender } & \multicolumn{2}{c}{ Intervention } & \multicolumn{2}{c}{ Control } \\
\cline { 2 - 5 } & $\mathbf{f ( n )}$ & $\mathbf{\%}$ & $\mathbf{f}(\mathbf{n})$ & $\mathbf{\%}$ \\
\hline Male & 5 & $22,7 \%$ & 5 & $22,7 \%$ \\
Female & 17 & $77,3 \%$ & 17 & $77,3 \%$ \\
\hline Total & 22 & $100 \%$ & 22 & $100 \%$ \\
\hline
\end{tabular}

The results of the research that was conducted based on gender showed that the majority of respondents were women as many as 17 people (77.3\%) were respondents in the intervention group and 17 people $(77.3 \%)$ respondents in the control group.
According to the research conducted by Murdiana et al (2017), it is stated that the majority of respondents are female. In addition, Anggita's research (2016) states that the child gender is related to the child's ability to reduce enuresis (bedwetting). Boys tend to experience bed wetting than girls.

Table 3 Distribution Frequency of Respondent Characteristics Based on Parents' Age

\begin{tabular}{lcccc}
\hline \multirow{2}{*}{$\begin{array}{c}\text { Parents } \\
\text { Age }\end{array}$} & \multicolumn{2}{c}{ Intervention } & \multicolumn{2}{c}{ Control } \\
\cline { 2 - 5 } & $\mathbf{f ( n )}$ & $\mathbf{\%}$ & $\mathbf{f ( n )}$ & $\mathbf{\%}$ \\
\hline $\begin{array}{c}\text { Age 26- } \\
\text { 35 year }\end{array}$ & 18 & $81,8 \%$ & 19 & $86,4 \%$ \\
$\begin{array}{l}\text { Age 36- } \\
\text { 45 year }\end{array}$ & 4 & $18,2 \%$ & 3 & $13,6 \%$ \\
\hline Total & 22 & $100 \%$ & 22 & $100 \%$ \\
\hline
\end{tabular}

The result show that the age of the respondents of parents are 26-35 years old as much 18 people $(81.8 \%)$ in the intervention group and 19 parents (86.4\%) in the control group. Based on the research of Johninsi (2018), it shows that most of the mother's age is 26-35 years, in which age the mother is busy in household chores.

Devi and Firdaus (2015) state that mothers in the age range 26-35 years old have many problems in the household 
or work so that they are not maximal in carrying out their roles properly. Research conducted by Atti and Nur (2014) states that the age of the respondents are mostly in the range of 26-30 years old, which is in early adulthood. It means that the increasing age of person can have an effect on the increase in the knowledge they get.

Table 4 Distribution Frequency of Respondent Characteristics Based on Parents' Occupation

\begin{tabular}{lcccc}
\multirow{2}{*}{$\begin{array}{c}\text { Parents' } \\
\text { Occupation }\end{array}$} & \multicolumn{2}{c}{ Intervention } & \multicolumn{2}{c}{ Control } \\
\cline { 2 - 5 } & $\mathbf{f}(\mathbf{n})$ & $\mathbf{\%}$ & $\mathbf{f ( n )}$ & $\mathbf{\%}$ \\
\hline Labour & 4 & $18,2 \%$ & 2 & $9,1 \%$ \\
Housewife & 14 & $63,6 \%$ & 5 & $22,7 \%$ \\
Private & 4 & $18,2 \%$ & 15 & $68,2 \%$ \\
\hline Total & 22 & $100 \%$ & 22 & $100 \%$ \\
\hline
\end{tabular}

The results of the research show that the majority of respondents are 14 people $(63.6 \%)$ housewives in the intervention group and 15 people $(68.2 \%)$ private in the control group. This is in line with Destiana's research (2017) which states that the majority of the respondents' parents work as housewives and in private companies.

According to the research conducted by Musfiroh and Wisudanintyas (2014), it is stated that housewives have relatively enough time for family, especially children. Mother's employment status can affect the opportunities and time spent in increasing knowledge by accessing information through electronic media and also participating in community activities such as posyandu and PKK.

Table 5 Distribution of Respondents Characteristics Based on Parental Education

\begin{tabular}{lcccc}
\hline \multirow{2}{*}{$\begin{array}{c}\text { Parents' } \\
\text { Education }\end{array}$} & \multicolumn{2}{c}{ Intervention } & \multicolumn{2}{c}{ Control } \\
\cline { 2 - 5 } & $\mathbf{f ( n )}$ & $\mathbf{\%}$ & $\mathbf{f ~ ( n )}$ & $\mathbf{\%}$ \\
\hline SD & 5 & $22,7 \%$ & 7 & $31,8 \%$ \\
SMP & 7 & $31,8 \%$ & 12 & $54,5 \%$ \\
SMA & 10 & $45,5 \%$ & 3 & $13,6 \%$ \\
\hline Total & 22 & $100 \%$ & 22 & $100 \%$ \\
\hline
\end{tabular}

The results of the research that has been carried out based on the level of education show that the majority of respondents' parents are $10 \quad(45.5 \%)$ parents from SMA in the intervention group and $12(54.5 \%)$ parents are from junior high school in the control group. Education has a very important role in determining the quality of humans. Being educated, human will also gain knowledge and information. The higher the education level of a person, the better his quality of life will be (Notoatmodjo, 2012). 
This is in line with Mujahidatul and Beny's research, (2014) which states that mostly the education level of junior high schools with a secondary education background, parents will also lack in understanding the problems that occur to their children because they lack insight and information about how to perform parents' roles properly (Supartini, 2014).

Table 6 Distribution of Toilet Learning Success in Toddlers Before being Given Hypno-parenting Education

\begin{tabular}{lccccc}
\hline Var & Min & Max & Mean & Med & SD \\
\hline $\begin{array}{l}\text { The } \\
\text { Success } \\
\text { of Toilet }\end{array}$ & 9 & 36 & 26,27 & 25,00 & 7,330 \\
Learning & & & & & \\
\end{tabular}

The results showed that the mean value of toilet learning success before being given hypno-parenting education for toddlers was 26.27 with a standard deviation of 7.330. This is in line with Yendrizal's research (2016) which stated that the average appetite for preschool children before hypno-parenting education is 1.29 .

According to the research conducted by Atti and Nur (2014), the mother's knowledge of toilet learning before being given toilet learning health education was in the sufficient category. Furthermore, research conducted by Mandasari and Ery (2016), states that the behavior of toilet training before providing health education on toilet training stimulation to mothers who have good behavior and adequate behavior, resulted in the majority of mothers are in the good category.

Table 7 Distribution of Toilet Learning Success for Toddlers After being Given Hypno-parenting Education

\begin{tabular}{llllll}
\hline Var & Min & Max & Mean & Med & SD \\
\hline The & & & & \\
Success & & & & & \\
of Toilet & 12 & 36 & 28,32 & 27,00 & 7,020 \\
Learning & & & & \\
Post test & & & & \\
\hline
\end{tabular}

The results showed that the mean value of toilet learning success after being given hypno-parenting education for toddlers was 28.32 with a standard deviation of 7.020. This is in line with Yendrizal's research (2016) which stated that the average appetite for preschool children after hypno-parenting is 1.79 .

According to the results of research conducted by Mandasari and Ery (2016), after health education of the stimulation of toilet training was carried out, the 
respondents who had good behavior increased to 17 respondents and there were 2 respondents in sufficient behavior. In addition, research conducted by Atti and Nur (2014), stated that a mother's knowledge of toilet learning after being given toilet learning health education is in the sufficient category.

2. Bivariate Analysis

Table 8 The Effect of Hypno-parenting Method Education on the Success of Toilet Learning for Toddlers

\begin{tabular}{lcccc}
\hline Var & Group & Phase & Result & $\begin{array}{c}\text { Explana- } \\
\text { tion }\end{array}$ \\
\hline & $\begin{array}{c}\text { Interven- } \\
\text { tion }\end{array}$ & $\begin{array}{c}\text { Pre test } \\
\text { Post test }\end{array}$ & 0,000 & $\begin{array}{c}\text { Not } \\
\text { Normal }\end{array}$ \\
The $\begin{array}{c}\text { Success } \\
\text { of Toilet } \\
\text { Learning }\end{array}$ & Control & $\begin{array}{l}\text { Pre test } \\
\text { Post test }\end{array}$ & 0,015 & $\begin{array}{c}\text { Not } \\
\text { Normal }\end{array}$ \\
\cline { 2 - 4 } & & &
\end{tabular}

The results showed that the $\mathrm{p}$ value $=$ 0.000 ( $\mathrm{p}$ value $<0.05$ ) so Ho was rejected and Ha was accepted so that education about the hypno-parenting method affected the success of toilet learning in toddlers.

This research is in line with the research conducted by Mandasari and Ery (2016) which stated that the $p$ value $=0.001(\mathrm{p}$ value $<0.05)$ indicates the influence of counseling on toilet training stimulation on behavior in toilet training for mothers who have toddlers.

According to the results of research conducted by Ros and Sunarsih (2016), stated that the $\mathrm{p}$ value $=0.002(\mathrm{p}$ value $<0.05$ ) indicates the effect of the pictorial module on increasing the success of toilet training in toddlers.

Table 9 The Differences of the Success of Toilet Learning in the Intervention Group and in the Control Group

\begin{tabular}{lcccc}
\hline \multicolumn{1}{c}{ Group } & n & Mean & $\begin{array}{c}\text { Asymp. } \\
\text { Sig } \\
\text { (2-tailed) }\end{array}$ & $\begin{array}{c}\text { Expla- } \\
\text { nation }\end{array}$ \\
\hline Intervention & 22 & 26,66 & 0,029 & $\begin{array}{l}\text { Ho re- } \\
\text { jected }\end{array}$ \\
Control & 22 & 18,34 & & \\
\hline
\end{tabular}

The results showed that there were differences in the success of toilet learning in the intervention group and the control group. The successful of toilet learning increased after hypnoparenting education was carried out in the intervention group and counseling on toilet learning in the control group. This is in line with the results of Mandasari's (2016) research, which stated that there are significant differences between the experimental group and the control group, and behavior in toilet training 
for mothers who have toddlers become better after being given education about stimulation of toilet training.

According to Rosiana's research (2014), the parents' knowledge between before and after being given health education about toilet training have significant differences, and their knowledge increases after getting health education about toilet training.

\section{CONCLUSIONS AND SUGGESTIONS}

\section{CONCLUSIONS}

a. The majority gender of respondents were women in the intervention group with 17 children and 17 in the control group. The majority of respondents were 3 years old in the intervention group with 11 children and 13 in the control group. Most of the 'parents' education was from high school in the intervention group with 10 people and from junior high school in the control group with 12 people. Most of the respondents' occupations were as housewives in the intervention group (14 people) and private jobs in the control group (15 people). b. Before having educated about hypnoparenting method, the results showed that the mean success of toilet learning was 26.27 with a standard deviation of 7.330 .

c. After having an education on the hypno-parenting method, the results showed that the mean success of toilet learning was 28.32 with a standard deviation of 7.020.

d. There is an effect of before toilet learning and after counseling about toilet learning. The results showed that the $\mathrm{p}$ value $=0.000(\mathrm{p}$ value $<0.05)$ so Ho was rejected and $\mathrm{Ha}$ was accepted so that education about the hypno-parenting method affected the success of toilet learning in toddlers (1-3 years) in Kampung Randusari Surakarta.

e. There is a difference in the effect of toilet learning in the intervention group and the control group 0.029 (p-value $<0.05$ ) so that Ho is rejected and $\mathrm{Ha}$ is accepted, which means that there is a difference between the intervention group and the control group. 


\section{SUGESSTIONS}

This research is expected to be applied by parents as a hypno-parenting therapy in the toilet learning process for toddlers.

The results of this study are expected to add to the literature, especially related to toilet learning in toddlers and hypnoparenting, which are complementary therapies.

\section{BIBLIOGRAPHIES}

Ammelda, R, Novayelinda, R, Erwin. 2013. Pengaruh Modeling Media Video dan Gambar terhadap Keberhasilan Toilet Training pada Anak Prasekolah. Program Studi ilmu keperawatan. Universitas Riau.

Anggita, Kesuma P. 2016. Hubungan Tingkat Pengetahuan Ibu tentang Toilet Training Terhadap Pelaksanaan Toilet Training pada Anak Usia Toddler di Kelurahan Sewu Surakarta. Program Studi S1 Keperawatan. Fakultas Ilmu kesehatan. Universitas Muhammadiyah Surakarta.

Armawati NM. 2011.Perubahan sikap ibu tentang toilet training anak usia 1-3 tahun setelah mendapatkan penyuluhan di Tegalboto. Jurnal penelitian kesehatan suara forikes. Volume II. No. 2.

Atti Y, Nur A. 2014. Pengaruh Pemberian Pendidikan Kesehatan Toilet Learning Terhadap Pengetahuan Ibu Pada Anak Usia Toddler Di Paud Mawar Rw 06 Kelurahan Tlogomas Malang. Jurnal CARE. Vol. 2. No.2

Destiana D. 2017. Hubungan Pola Asuh Orang Tua terhadap Pelaksanaan Toilet Training pada Anak di PAUD Lembaga Pemberdayaan Perempuan dan Anak (LPA) Yayasan Mujahidin Kota Pontianak. Jurnal Proners. Vo. 3. No. 1

Devi Rahayu M, Firdaus. 2015. Hubungan Peran Orang Tua Dengan Kemampuan Toilet Training Pada Anak Usia Toddler Di PAUD Permata Bunda RW 01 Desa Jati Selatan 1 Sidoarjo. Jurnal Ilmiah Kesehatan. Vol. 8. No.1. Februari 2015. Nasrul E. 2011. Dasar-dasar Keperawatan Kesehatan Masyarakat. Jakarta:EGC.

Erwin. 2013. Karakteristik Anak Jalanan dan Bentuk-bentuk Kekerasan terhadap Anak Jalanan di Kota Padang Provinsi Sumatera Barat. Antropologi Indonesia Sigmund F. 1939. The Ego and The Id. London: The Hogath Press LTD. 
Johninsi, P, Julia, R, dan Yolanda, B. 2018. Hubungan Peran Orang Tua Dengan Kemampuan Toilet Training pada Anak Pra Sekolah di TK GMIM Sion Sentrum Sendangan Kawangkoan Satu. Jurnal Keperawatan. Vol.6 No. 1. Februari 2018.

Kemenkes RI. 2013. Riset Kesehatan Dasar, RISKESDAS. Jakarta: Balitbang Kemenkes RI.

Kiftiyah, Wardani, RA, Rosyidah, NN. 2018. Pengaruh Metode Demonstrasi tentang Toilet Training terhadap Peningkatan Pembelajaran Toilet Training pada Anak Usia 3 Tahun. Jurnal Nurse and Health. ISSN: 2088-9909.

Mandasari S, Ery, K. 2016. Penyuluhan Tentang Stimulasi Toilet Training Terhadap Perilaku Dalam Toilet Training Pada Ibu Yang Mempunyai Anak Toddler. Fakultas Ilmu kesehatan. Universitas 'Aisyiyah Yogyakarta.

Mendur, J P. Rottie, Julia \& Bataha Yolanda. 2018. Hubungan Peran Orang tua Dengan Kemampuan Toilet Training pada Anak Pra Sekolah di TK GMIM Sion Sentrum Sendangan Kawangkoan Satu. E-journal Keperawatan. Vol.6. No.1.
Mujahidatul M, Beny LW. 2014. Penyuluhan Terhadap Sikap Ibu Dalam Memberikan Toilet Training Pada Anak. Jurnal Kesehatan Masyarakat. Vo. 9 No. 2. Januari 2014.

Murdiana S, Putu E, Lasri. (2017). Hubungan Kemampuan Stimulasi Orang Tua dengan Tingkat Keberhasilan Toilet Learning pada Anak Usia Toddler di PAUD Wilayah Kelurahan Tlogomas Kota Malang. Nursing news. Volume 2. Nomor 3.

Musfiroh, Mujahidatul, Wisudaningtyas, BL. 2014. Penyuluhan terhadap Sikap Ibu Dalam Memberikan Toilet Training pada Anak. Jurnal Kesehatan Masyarakat. ISSN 1858-1196.

Soekidjo N. 2014. Promosi Kesehatan dan Ilmu Perilaku Kesehatan. Jakarta:Rineka Cipta.

Rahayu DM dan Firdaus F. (2017). Hubungan peran orang tua dengan kemampuan toilet training pada anak usia toddler di PAUD Permata Bunda RW 01 Desa Jatian Selatan 1 Sidoarjo. J Heal Sci. $2017 ; 8(1)$

Ros Endah HP, Sunarsih, Rahayu. Pengaruh Modul Bergambar Terhadap Peningkatan Keberhasilan Toilet 
Training Anak Toddler di puskesmas

Sibela Surakarta. Jurnal Terpadu Ilmu

Kesehatan. Vol 6. No. 1. Mei 2016

Rosiana P. 2014. Pengaruh Pendidikan kesehatan tentang Toilet Training Anak Usia 1-3 Tahun Terhadap pengetahuan Ibu di Desa Sambon Banyudono Boyolali. Fakultas Ilimu Kesehatan. Universitas Muhammadiyah Surakarta. Siswoyo, Dwi, dkk. 2011. Ilmu Pendidikan. Yogyakarta: UNY Press.

Soetjiningsih. 2012. Perkembangan Anak dan Permasalahannya dalam Buku Ajar I Ilmu Perkembangan Anak dan Remaja. Jakarta : Sagungseto.

Suhendri. 2011. Pengaruh Hypnoparenting terhadap Peningkatan Nafsu Makan Anak Usia Prasekolah yang Sulit Makan.

Suherman. 2010. Buku Saku Perkembangan Anak. Jakarta: EGC.

Supartini. 2012. Buku Ajar Konsep Dasar Keperawatan Anak. Jakarta: EGC.
Survei Kesehatan Rumah Tangga (SKRT). 2012. Profil Indonesia Sehat tahun 2012. Diakses pada tanggal 29 Oktober 2018. www.depkes.go.id

Sutiyono, A. 2010. Dahsyatnya Hypnoparenting. Depok: Penebar Plus.

Umami, S. D. 2011. Hubungan Pola Asuh Orang Tua dengan Keberhasilan Toilet Traning Pada Anak Usia 4-6 Tahun Di TK Puspasari I Sidomoyo Godean Sleman DI Yogyakarta. STIKES'Aisyiyah Yogyakarta

Wong LDonna. 2009. Buku Ajar Keperawatan Pediatiatrik. Vol. 1. Edisi 6. Jakarta: EGC.

Willi W, Andri H. 2009. Dahsyatnya Hypnosis. Jakarta: Visi Media.

Yendrizal J. 2014. Pengaruh Hypnoparenting terhadap Peningkatan Nafsu Makan Anak Usia Prasekolah yang Sulit Makan di Surau Pinang. Program Studi Imu kesehatan. STIKes Perintis Sumbar. 